Printed ISSN : $2406-7415$

Electronic ISSN : $2655-9919$

DOI: http://dx.doi.org/10.35137/jabk.v8i3.594

JURNAL AKUNTANSI DAN BISNIS KRISNADWIPAYANA

Volume 8 Nomor 3 (September - Desember) 2021

\title{
PENGARUH STRUKTUR MODAL, PROFITABILITAS, DAN KEBIJAKAN DIVIDEN TERHADAP NILAI PERUSAHAAN OTOMOTIF (STUDI EMPIRIS PADA PERUSAHAAN YANG TERDAFTAR DI BURSA EFEK INDONESIA PERIODE 2017 SAMPAI 2019)
}

\author{
Siti Nurlatifah ${ }^{1}$ \\ ${ }^{1}$ Fakultas Ekonomi Universitas Krisnadwipayana \\ Jalan Unkris Jatiwaringin Jakarta Timur \\ Handphone Penulis : 089656344016, e-mail: ifa.latifah.unkris915@gmail.com
}

\begin{abstract}
The purpose of this study is to determine the effect of The Capital Structure, Profitability and Dividend Policy on Firm Value. The research method is carried out by first determining the object of research, population and sample as well as data collection techniques. In this research, the type used is secondary data The research method is to use quantitative analysis which analyzes the description of the data through the data by means of the minimum, maximum, average and standard deviation of each variable under study. . This study uses simple regression analysis techniques and multiple regression and uses SPSS 25 program analysis tools. From the results of the research that has been done, it is found that the Capital Structure, Profitability and Dividend Policy have a simultaneous and partial effect on the Value of Automotive Companies Listed on the Indonesia Stock Exchange for the Period 2017 to 2019
\end{abstract}

Keywords : The Capital Structure, Profitability and Dividend Policy and Firm Value

\section{PENDAHULUAN}

Kondisi kinerja keuangan saat ini cenderung fluktuatif karena kondisi keuangan perusahaan yang tidak stabil. Oleh karena itu, perusahaan yang memiliki kinerja keuangan yang baik akan menjadi pertimbangan utama bagi para investor. Tren Kinerja Keuangan Perusahaan Otomotif dalam 5 Tahun terakhir (dengan nilai rata rata industri) dapat dilihat pada grafik berikut ini:

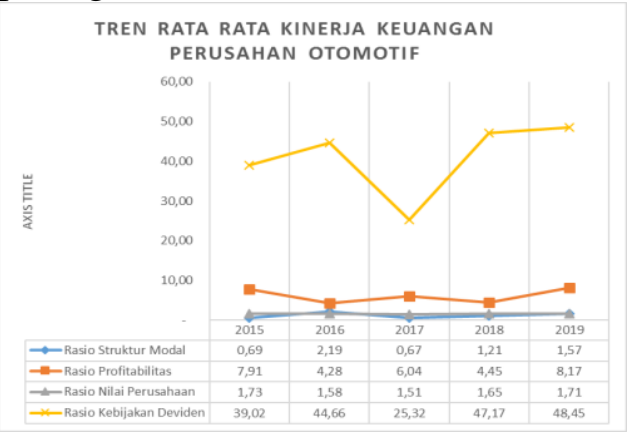

Sumber: Data diolah (IDX, 2020)

Copyright (c) 2021 Siti Nurlatifah, SE., M.Si.
Gambar 1. Tren Rata Rata Kinerja Keuangan Perusahaan Otomotif 5 Tahun terakhir.

Pada Gambar 1 diketahui bahwa untuk nilai tertinggi struktur modal adalah pada tahun 2016 yaitu sebesar 2,19\%. Untuk nilai tertinggi profitabilitas adalah pada tahun 2019 yaitu sebesar $8,17 \%$. Untuk nilai tertinggi nilai perusahaan adalah pada tahun 2015 yaitu sebesar 1,73\%. Untuk nilai tertinggi kebijakan dividen adalah pada tahun 2019 yaitu sebesar $48,45 \%$.

Nilai perusahaan merupakan hasil dari kinerja perusahaan tersebut dalam satu periode. Semakin baik kinerja keuangan suatu perusahaan maka semakin mudah untuk menarik investor untuk menginvestasikan dananya kepada perusahaan. Selain itu, semakin baik kinerja suatu perusahaan maka 
DOI: http://dx.doi.org/10.35137/jabk.v8i3.594

akan meningkatkan nilai saham dan memberikan pengembalian hasil atau return yang diharapkan oleh investor. Banyak faktor yang mempengaruhi nilai suatu perusahaan salah satunya adalah tingkat profitabilitas perusahaan.

Tingkat profitabilitas perusahaan tercermin pada harga saham yang ditunjukkan dengan cara bagaimana perusahaan memanfaatkan aset atau harta yang dimilikinya untuk memperoleh laba maksimal. Apabila kemampuan perusahaan untuk menghasilkan laba meningkat, maka harga saham juga akan meningkat (Ria 2013).

Selain itu, perusahaan dengan struktur modal yang tidak baik dan hutang yang sangat besar akan memberikan beban berat kepada perusahaan sehingga perlu adanya keseimbangan yang optimal dalam pemanfaatan modal sendiri dan hutang agar dapat memaksimalkan nilai perusahaan. Semakin tinggi modal yang berasal dari modal sendiri, hal tersebut menandakan rendahnya hutang yang dimiliki perusahaan tersebut. Dengan kondisi tersebut perusahaan akan memberikan insentif yang lebih besar kepada pemiliknya, yang akan meningkatkan pembayaran hasil investasi dan pada akhirnya akan meningkatkan nilai perusahaan dari naiknya harga saham.

Debt to Equity Ratio (DER) adalah salah satu rasio yang memberikan gambaran mengenai struktur modal yang dimiliki oleh perusahaan sehingga dapat diketahui tingkat risiko tak terbayarkan suatu hutang. Debt to Equity Ratio (DER) juga menunjukkan seberapa besar tingkat hutang perusahaan. Semakin besar hutang yang dimiliki biaya yang harus dikeluarkan juga semakin tinggi. Yang pada akhirnya hutang tersebut akan menjadi beban bagi perusahaan dan dapat menurunkan tingkat kepercayaan investor.
URNAL AKUNTANSI DAN BISNIS KRISNADWIPAYANA

Volume 8 Nomor 3 (September - Desember) 2021

Selain kedua hal tersebut yaitu tingkat profitabilitas dan struktur modal. Kebijakan dividen yang diterapkan perusahaan mempunyai daya tarik tersendiri bagi investor terhadap suatu perusahaan. Semakin tinggi tingkat dividen yang diterapkan perusahaan, semakin baik nilai perusahaan tersebut dimata investor. Meskipun menarik, kebijakan dividen bisa menjadi masalah tersendiri bagi perusahaan, karena besarnya dividen menunjukkan seberapa besar yang diterima oleh investor atas dana yang di investasikan di perusahaan tersebut. Keinginan perusahaan dan investor bertolak belakang, perusahaan menghendaki laba yang diperoleh bisa di tahan untuk meningkatkan perusahaan sedangkan investor menghendaki laba tersebut di bagikan dalam bentuk dividen.

Dari penjelasan Pendahuluan masalah diatas, maka peneliti ingin menguji kembali terkait hal yang tidak konsisten tersebut dengan data yang berbeda dalam penelitian yang berjudul "Pengaruh Struktur Modal, Profitabilitas dan Kebijakan Dividen terhadap Nilai Perusahaan Otomotif yang Terdaftar di Bursa Efek Indonesia Periode 2017 Sampai 2019”.

\section{KAJIAN TEORI}

\section{Signaling Theory}

Menurut Jama'an (2008) Signaling Theory menjelaskan tentang bagaimana sebuah perusahaan memberikan sinyal kepada pengguna laporan keuangan. Sinyal ini berupa informasi mengenai apa yang sudah dilakukan oleh manajemen untuk merealisasikan keinginan pemilik. Signaling teory juga dapat diartikan sebagai penjelasan dari asimetri informasi. Asimetri informasi bisa terjadi karena pihak 
DOI: http://dx.doi.org/10.35137/jabk.v8i3.594

manajemen mempunyai informasi lebih banyak mengenai prospek perusahaan.

Salah satu jenis informasinya adalah laporan tahunan. Informasi yang diungkapkan dalam laporan tahunan yaitu informasi yang berkaitan dengan laporan keuangan dan yang tidak berkaitan dengan laporan keuangan.

\section{Nilai Perusahaan}

Menurut theory of the firm, tujuan utama perusahaan adalah meningkatkan nilai perusahaan (value of the firm) (Salvatore 2005) karena dengan nilai perusahaan yang tinggi akan diikuti oleh tingginya kemakmuran pemegang saham (Brigham 2011). Ada tiga jenis penilaian terhadap nilai saham perusahaan antara lain penilaian atas nilai pasar (market value), nilai buku (book value), dan nilai intrinsik (intrinsic value) (Alicia 2013).

Menurut pendapat Husnan dan Eny (2006) bagi perusahaan yang belum go public nilai perusahaan merupakan sejumlah biaya yang bersedia dikeluarkan oleh para investor jika perusahaan dijual, sedangkan bagi perusahaan yang sudah go public nilai perusahaannya dapat dilihat dari besarnya nilai saham yang ada di pasar modal.

Nilai saham didefinisikan dengan jumlah lembar saham dikalikan dengan nilai pasar per lembar saham ditambah nilai hutang, dengan asumsi jika nilai hutang konstan maka secara langsung peningkatan nilai saham akan meningkatkan nilai perusahaan.

Selain itu, menurut Keown (2010) terdapat beberapa alternatif untuk menilai perusahaan di antaranya adalah:

\section{a. Price Book Value}

Price Book Value adalah rasio yang menggambarkan seberapa besar pasar menghargai nilai buku saham suatu perusahaan. Semakin besar nilai Price Book
URNAL AKUNTANSI DAN BISNIS KRISNADWIPAYANA

Volume 8 Nomor 3 (September - Desember) 2021

Value maka akan menunjukkan meningkatnya kepercayaan pasar terhadap rencana kemajuan perusahaan tersebut.

Rasio Price Book Value dihitung dengan membagi nilai pasar dari saham dengan nilai buku saham tersebut.

\section{b. Nilai Buku}

Nilai Buku digunakan sebagai titik awal untuk analisa kondisi Perusahaan walau tidak menghitung nilai pasar dari suatu perusahaan secara keseluruhan. Rasio Nilai Buku dihitung dengan membagi total aset setelah dikurangi total hutang dengan jumlah saham yang beredar.

\section{c. Enterprise Value}

Enterprise Value merupakan cara menilai perusahaan dengan memperhitungkan kas dan hutang sebagai alat ukur kewajaran nilai perusahaan. Rasio Enterprise Value dihitung dengan menjumlahkan Hasil kali Harga pasar saham dan jumlah pasar saham yang beredar dengan hutang setelah dikurangi kas.

\section{d. Price Earning Ratio Method}

Metode ini butuh informasi terkait proyeksi futures earning Perusahaan, expected return for equity investment, expected return on investment dan historical price earning ratio. Informasi tersebut digunakan untuk menentukan target price earning ratio dan kemudian membandingkan dengan rata - rata industrinya.

\section{e. Discounted Cashflow Approach}

Metode ini dilakukan dengan mendiskontokan expected cashflow dan melakukan perbandingan dengan market value perusahaan. 
DOI: http://dx.doi.org/10.35137/jabk.v8i3.594

\section{f. Nilai Appraisal}

Nilai ini dapat di dapat dari perusahaan appraisal independent. Nilai ini selalu dihubungkan dengan biaya penempatan. Nilai ini akan bermanfaat dalam kondisi tertentu seperti dalam perusahaan finance, perusahaan sumber daya alam atau organisasi yang mengalami kerugian dalam kegiatan operasionalnya.

\section{g. Nilai Pasar Saham}

Nilai ini dinyatakan dalam kuotasi pasar modal adalah pendekatan lain untuk memperkirakan nilai bersih dari suatu bisnis. Pendekatan nilai ini adalah salah satu sering dipergunakan dalam menilai perusahaan besar dan sering juga digunakan untuk menentukan harga perusahaan.

\section{h. Nilai Chop - Shop}

Pendekatan chop - shop pertama kali diperkenalkan oleh Dean Lebaron dan Lawrence Spei dell of Batterymarch Management dengan menekankan identifikasi perusahaan multi industri yang berada di bawah nilai dan akan bernilai lebih apabila dipisahkan menjadi bagian-bagian.

Penelitian ini menggunakan rasio Price to Book Value (PBV) untuk menghitung nilai perusahaan. Price to Book Value merupakan rasio untuk mengukur nilai perusahaan. Menurut Ang (2010:30), PBV merupakan rasio untuk mengukur kinerja harga pasar saham terhadap nilai bukunya. PBV menunjukkan kemampuan perusahaan menciptakan nilai perusahaan dalam bentuk harga terhadap modal yang tersedia.

Dengan semakin tinggi PBV berarti perusahaan dapat dikatakan berhasil menciptakan nilai dan kemakmuran pemilik. Karena semakin besar nilai PBV semakin meningkat nilai perusahaan di mata para pemodal jika
Volume 8 Nomor 3 (September - Desember) 2021 dibandingkan dengan dana yang telah ditanamkan di perusahaan (Doni, 2012:6). Ang (2010:32) merumuskan PBV sebagai berikut:

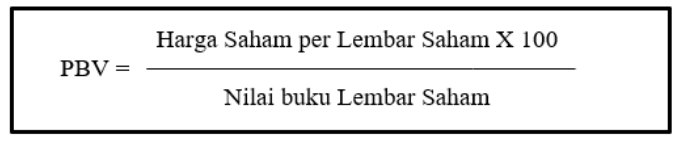

\section{Struktur Modal (Leverage)}

Menurut Wild, et al (2005) struktur modal merupakan komposisi pendanaan antara ekuitas (pendanaan sendiri) dan utang pada suatu perusahaan. Hal senada juga diungkapkan oleh Ross bahwa struktur modal adalah gabungan dari hutang jangka panjang dan sekuritas yang dipakai perusahaan untuk membiayai kegiatan operasionalnya. Sedangkan Menurut Neil Seitz (1999) struktur modal merupakan gabungan dari sumber hutang jangka panjang yang meliputi hutang, saham biasa, dan saham umum.

Untuk mengukurnya digunakan rasio leverage. Menurut Sartono (2001) leverage adalah Penggunaan asset dan sumber dana (source of funds) oleh pihak yang memiliki biaya tetap (beban tetap) dengan tujuan untuk meningkatkan keuntungan potensial pemegang saham. Istilah leverage biasanya dipergunakan untuk menggambarkan kemampuan perusahaan menggunakan aktiva atau aset yang mempunyai biaya tetap (fixed cost assets or funds) untuk meningkatkan tingkat pengembalian (return) bagi pemilik perusahaan.

Berdasarkan pada pengertian di atas maka dapat disimpulkan leverage adalah kemampuan perusahaan dalam memanfaatkan aktiva dan atau aset yang mempunyai beban tetap (fixed cost assets or funds) untuk memaksimalkan kekayaan pemilik perusahaan.

Ada beberapa rasio yang digunakan untuk mengukur tingkat leverage suatu perusahaan. 
DOI: http://dx.doi.org/10.35137/jabk.v8i3.594

Menurut Husnan dan Pudjiastuti (2012) jenisjenis rasio leverage adalah:

a. Debt to Equity Ratio, rasio ini membandingkan antara hutang dengan modal sendiri.

b. Times Interest Earned, rasio ini mengukur seberapa banyak laba operasi (ditambah penyusutan) untuk membayar bunga hutang.

c. Debt Service Coverage, kewajiban finansial yang timbul karena menggunakan hutang untuk membayar bunga dan sewa guna (leasing). Ada juga kewajiban dalam bentuk pembayaran angsuran pokok pinjaman.

Debt to Equity Ratio merupakan rasio untuk mengukur leverage. Menurut Harahap (2007:86) debt to equity ratio adalah perbandingan antara hutang dan modal. Sedangkan menurut Diah Andarini (2007) dalam Dwipratama (2009:7) debt to equity ratio adalah rasio untuk mengukur tingkat penggunaan utang terhadap total shareholder's equity yang dimiliki perusahaan.

Adapun rumus DER adalah (Harahap, 2007)

$$
\text { DER }=\frac{\text { Total Hutang }}{\text { Total Modal }}
$$

\section{Kebijakan Dividen}

Menurut Robert Ang, dividen merupakan nilai pendapatan bersih perusahaan setelah pajak dikurangi dengan laba ditahan (retained earnings) yang ditahan sebagai cadangan bagi perusahaan (ang, 2010). Dividen ini untuk dibagikan kepada para pemegang saham sebagai keuntungan dari laba perusahaan.

Besar nominal dividen yang berikan kepada para pemegang saham tergantung dari perusahaan. Kebijakan dividen memegang peranan penting dalam menentukan nilai perusahaan. Stockholder (pemegang saham) memandang dividen sebagai tanda kemampuan
Volume 8 Nomor 3 (September - Desember) 2021 perusahaan dalam meningkatkan pendapatan. Manajer Finance harus mampu mengambil kebijakan dividen yang optimal, dimana manajer harus mampu menyeimbangkan dividen saat ini dan tingkat pertumbuhan dividen di masa yang akan datang, dengan tujuan untuk meningkatkan nilai perusahaan.

Dividen merupakan bagian laba bersih yang dibagikan kepada pemegang saham. Ada dua jenis dividen, yaitu dividen saham preferen dan saham biasa. Dividen saham preferen yang dibayarkan secara tetap dalam jumlah tertentu, dan dividen saham biasa yang dibayarkan kepada pemegang saham apabila perusahaan mendapatkan laba. Dengan demikian semakin besar dividen yang dikeluarkan oleh perusahaan akan semakin besar juga nilai perusahaan atau harga saham (sutrisno 2009).

Dividend Payout Ratio adalah rasio antara dividen yang dibayarkan dibandingkan dengan jumlah laba bersih per lembar saham yang diperoleh perusahaan (Dwi 2013:8). Besarnya dividend payout ratio dijadikan ukuran oleh para investor yang hendak menanam modal pada saham di bursa efek. Dividen merupakan return yang dinantikan oleh investor sekaligus tanda bahwa perusahaan berada pada posisi profitabilitas yang tinggi (Ria 2013).

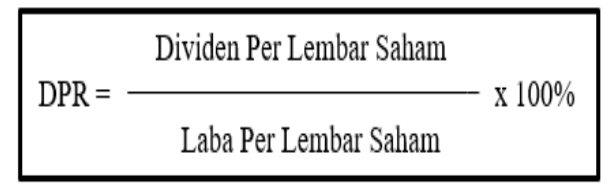

\section{Profitabilitas}

Menurut Brigham (2011) rasio profitabilitas adalah:

"A group of ratios that show the combined effects of liquidity, asset management, and debt and operating results." Artinya sekumpulan rasio yang menunjukkan tentang perpaduan antara 
DOI: http://dx.doi.org/10.35137/jabk.v8i3.594

likuiditas, manajemen aktiva, hutang, dan hasil operasi usaha.

Menurut Gitman (2006) rasio profitabilitas adalah:

"These measures enable the analyst to evaluate the firm's profit with respect to a given level of sales, a certain level of assets, or the owners investment". Artinya rasio yang memungkinkan analis untuk menilai tingkat keuntungan perusahaan dari penjualan, tingkat aktiva tertentu, atau investasi pemilik perusahaan.

Profitabilitas adalah kemampuan perusahaan memperoleh laba dalam hubungannya dengan total aktiva, penjualan, maupun modal sendiri.

Dari beberapa definisi di atas dapat diambil kesimpulan bahwa rasio profitabilitas adalah rasio yang menggambarkan tentang kemampuan perusahaan dalam menghasilkan laba (keuntungan).

Return on Assets (ROA) merupakan salah satu rasio profitabilitas. Menurut Dendawijaya (2009) rasio ini digunakan untuk mengukur kemampuan manajemen dalam memperoleh keuntungan (laba) secara keseluruhan. Semakin tinggi ROA, semakin tinggi juga tingkat keuntungan yang diperoleh perusahaan tersebut dan semakin baik posisi perusahaan tersebut dari segi penggunaan aset.

Menurut Hanafi dan Halim (2009), Return on Assets (ROA) merupakan rasio keuangan perusahaan yang mengukur kemampuan perusahaan menghasilkan keuntungan atau laba pada tingkat pendapatan, aset dan modal saham tertentu. Laba bersih (net income) merupakan ukuran pokok keseluruhan keberhasilan perusahaan.

Jadi, Return on asset merupakan salah satu rasio profitabilitas yang mengukur efektifitas perusahaan dalam memperoleh laba dari aset yang digunakan. Semakin tinggi ROA semakin efisien operasional perusahaan dan sebaliknya, rendahnya ROA dapat disebabkan oleh
Volume 8 Nomor 3 (September - Desember) 2021 banyaknya aset perusahaan yang menganggur, investasi dalam persediaan terlalu banyak, kelebihan uang kertas, aktiva tetap beroperasi dibawah normal dan lain-lain sehingga menurunkan profitabilitas perusahaan.

Secara matematis ROA dapat dirumuskan sebagai berikut:

$$
\text { ROA }=\frac{\text { Laba Sebelum Pajak }}{\text { Jumlah Aktiva Perusahaan }}
$$

\section{Industri Otomotif}

Industri otomotif ialah industri yang merancang, mengembangkan, memproduksi, memasarkan, dan menjual kendaraan.

Menurut Gaikindo (2016) Industri otomotif secara umum dibagi menjadi 6 (enam) bagian yaitu:

1. Industri Pemegang Merek (Pemegang Lisensi atau Prinsipal), yang melakukan perancangan dimulai dari: product planning, styling, prototyping, homologation, desain teknis (engineering design) dan hal-hal lain yang berhubungan dengan perancangan sebuah kendaraan dari mulai tidak ada menjadi ada dalam bentuk prototype yang kemudian melakukan uji coba (riset) terhadap prototype tersebut dengan berbagai macam standarisasi pengujian-pengujian yang berlaku dan kemudian melakukan perbaikan-perbaikan terhadap prototype tersebut sampai kemudian prototype tersebut dianggap layak untuk diproduksi. Setelah prototype sudah diuji dan dilakukan perbaikan-perbaikan lalu prinsipal kemudian merancang industri untuk membuat kendaraan prototype tersebut dalam jumlah banyak.

2. Industri Perakitan atau sering disebut Agen Tunggal Pemegang Merek (ATPM), Agen 
DOI: http://dx.doi.org/10.35137/jabk.v8i3.594

Pemegang Merek (APM) yang melaksanakan produksi kendaraan sesuai dengan arahan teknis dari pemegang merek. Untuk melaksanakan perakitan bisa dilakukan oleh pemegang merek itu sendiri, atau bekerjasama dengan investor lain untuk memproduksi kendaraan rancangan dari pemegang merek. Industri perakitan hanya melaksanakan standarisasi teknis yang diberikan oleh pemegang merek, adapun untuk pengembangan teknis perancangan dilaksanakan oleh pemegang merek.

3. Industri Karoseri adalah industri yang melakukan perubahan dari bodi kendaraan yang diproduksi oleh industri perakitan untuk melayani kebutuhan pasar tertentu seperti mobil box, bis, truk dan lain-lain. Industri karoseri menggunakan platform yang dirancang oleh pemegang merek dengan mengacu pada spesifikasi teknis kendaraan yang ditentukan oleh pemegang merek.

4. Industri Modifikator adalah industri yang melakukan perubahan modifikasi kendaraan mulai dari bodi, mesin, dan bagian-bagian lain sesuai dengan kebutuhan atau keinginan sang modifikator atau pasar dengan menggunakan platform dari pemegang merek.

5. Industri Perbengkelan / After Sales adalah industri jasa yang melakukan perbaikan dan perawatan dari kendaraan.

6. Industri Komponen, adalah industri yang melakukan pembuatan/ manufaktur untuk komponen-komponen otomotif sesuai dengan standarisasi teknis dari pemegang merek. Komponen yang dibuat bisa dibagi dalam 2 kategori yaitu: komponen OEM (komponen yang digunakan untuk industri perakitan) dan Komponen After Market (komponen yang digunakan untuk perbaikan).
URNAL AKUNTANSI DAN BISNIS KRISNADWIPAYANA

Volume 8 Nomor 3 (September - Desember) 2021

\section{Kerangka Konseptual}

Berdasarkan penjelasan diatas maka dibuatlah kerangka Konseptual dibawah ini yang akan digunakan dalam penelitian:

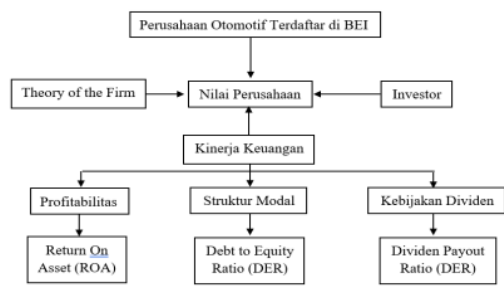

Sumber: (data diolah oleh peneliti)

Gambar 2. Kerangka Konseptual

Dari Gambar 2 diketahui kerangka konseptual penelitian ini, dimana tujuan utama perusahaan dalam hal ini perusahaan otomotif adalah meningkatkan nilai perusahaan. Untuk melihat bagaimana kinerja perusahaan para investor dapat melihat dari kinerja keuangan perusahaan tersebut. Kinerja keuangan ini dapat diukur melalui 3 hal yaitu profitabilitas dengan proksi rasio Return On Asset (ROA), Struktur Modal dengan proksi rasio Debt Equity Ratio (DER) dan Kebijakan Dividen dengan proksi rasio Deviden Payout Ratio (DPR).

Dari penjelasan kerangka konseptual di atas maka dibuatlah kerangka model penelitian seperti dalam gambar 3 berikut ini:

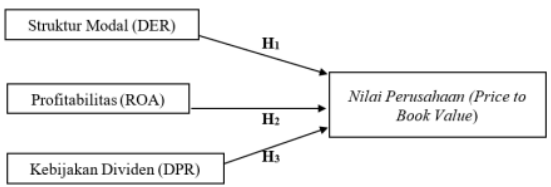

Gambar 3 Kerangka Model Penelitian

Keterangan:

DER = Debt Equity Ratio

$\mathrm{ROA}=$ Return On Asset

DPR = Deviden Payout Ratio 
DOI: http://dx.doi.org/10.35137/jabk.v8i3.594

Hipotesis berfungsi sebagai pegangan sementara atau jawaban sementara yang masih harus dibuktikan kebenarannya di dalam kenyataan (empirical Verification), percobaan (experimentation) atau praktik (implementation). Hipotesis yang diajukan dalam penelitian ini adalah sebagai berikut:

1. H1 : Struktur Modal (DER) mempunyai pengaruh secara parsial terhadap nilai perusahaan

2. $\mathrm{H} 2$ : Profitabilitas (ROA) mempunyai pengaruh secara parsial terhadap nilai perusahaan

3. H3 : Kebijakan Dividen (DPR) mempunyai pengaruh secara parsial terhadap nilai perusahaan

4. H4 : Struktur Modal (DER), Profitabilitas (ROA), Kebijakan Dividen (DPR), mempunyai pengaruh secara simultan terhadap nilai perusahaan

\section{METODE PENELITIAN}

Jenis penelitian ini merupakan metode kuantitatif, karena data yang digunakan adalah berupa angka. Dari angka yang diperoleh tersebut digunakan dalam analisis data. Penelitian ini terdiri dari 3 (tiga) variabel yaitu Struktur Modal dengan proksi rasio Debt Equity Ratio (DER), Profitabilitas dengan proksi rasio Return On Asset (ROA), dan Kebijakan Dividen dengan proksi rasio Deviden Payout Ratio (DPR).

Penelitian ini menggunakan data sekunder yaitu laporan keuangan tahunan setiap Perusahaan perusahaan Otomotif yang terdaftar di Bursa Efek Indonesia (BEI) tahun 2017 - 2019.

Metode pengumpulan data adalah menggunakan teknik dokumentasi dengan cara mengambil data laporan keuangan tahunan perusahaan Otomotif yang terdaftar di Bursa Efek Indonesia (BEI) tahun 2017-2019. Berjumlah 14
URNAL AKUNTANSI DAN BISNIS KRISNADWIPAYANA

Volume 8 Nomor 3 (September - Desember) 2021 perusahaan yang diperoleh dari Bursa Efek Indonesia per November 2020.

Dalam menentukan sampel penelitian ini menggunakan purposive sampel, yaitu sampel dipilih berdasarkan tujuan penelitian. Adapun kriteria yang digunakan dalam pemilihan sampel pada penelitian ini adalah sebagai berikut : (1) Perusahaan Otomotif yang terdaftar di BEI untuk tahun 2017 - 2019. 2. Menyediakan laporan tahunan lengkap selama tahun 2017 - 2019. 3. Perusahaan Otomotif yang memperoleh pendapatan laba positif dari tahun 2017 - 2019.

Teknik analisis data antara lain: (1) Uji Asumsi Klasik yaitu terdiri dari uji normalitas, uji multikolinearitas, uji heteroskedastisitas, dan autokorelasi data. (2) Uji Kelayakan Model (Uji F). (3) Uji Signifikan Parsial (Uji t) (4) Koefisien Determinasi $\left(\mathrm{R}^{2}\right)$. (5) Analisis Regresi Linear.

\section{HASIL PENELITIAN DAN PEMBAHASAN}

\section{Hasil Penelitian}

\section{Uji Asumsi klasik}

Hasil uji multikolonearitas menghasilkan perhitungan nilai tolerance dari masing-masing variabel independen lebih besar dari 0,10, yaitu untuk variabel Debt Equity Ratio sebesar 0,890, variabel Return On Asset sebesar 0,929, dan variabel Deviden Payout Ratio sebesar 0,847 yang berarti tidak ada korelasi antara variabel independent.

Sedangkan Nilai dari hasil variance inflation faktor (VIF) dari masing-masing variabel independen diketahui kurang dari 10, yaitu untuk variabel Debt Equity Ratio sebesar 1,124, variabel Return On Asset sebesar 1,077, dan variabel Deviden Payout Ratio sebesar 1,181. Jadi dari penjelasan tersebut dapat disimpulkan bahwa 
DOI: http://dx.doi.org/10.35137/jabk.v8i3.594

tidak ada multikolonieritas antara variabel independen dalam model regresi.

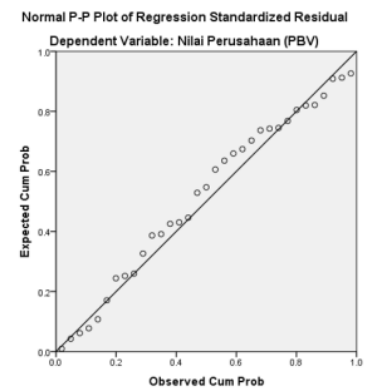

Gambar 5. grafik scatterplots

Hasil uji Normalitas dari grafik scatterplots terlihat bahwa adanya titik yang menyebar dan disekitar garis diagonal serta penyebarannya mengikuti arah garis diagonal. Hal tersebut membuktikan bahwa model regresinya telah memenuhi asumsi normalitas.

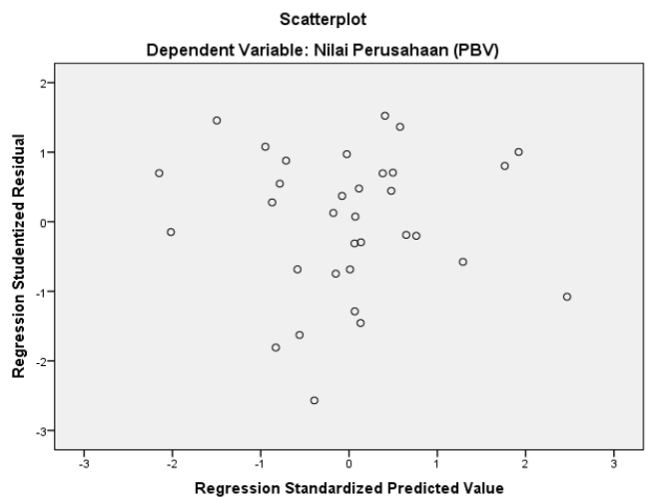

Gambar 6. Hasil uji Heteroskedastisitas dari grafik scatterplots.

Hasil uji Heteroskedastisitas dari grafik scatterplots pada kinerja keuangan pada terlihat bahwa titik menyebar secara acak tidak membentuk pola tertentu yang jelas, seperti bergelombang, melebar kemudian menyempit. Selain itu titik-titik tersebut menyebar diatas dan dibawah angka pada sumbu Y, maka dapat disimpulkan bahwa data adalah homogen.
Volume 8 Nomor 3 (September - Desember) 2021

\section{Uji Kelayakan Model (Uji F)}

Pengujian hipotesis ini yaitu untuk mengetahui pengaruh antara seluruh variabel independen (bebas) dengan variabel dependen (terikat). Dalam hipotesis penelitian ini, diduga bahwa seluruh variabel DER (X1), variabel ROA (X2) dan variabel DPR (X3) secara serempak mempengaruhi Nilai Perusahaan (PBV) (Y).

Berdasarkan hasil perhitungan menunjukkan Signifikansi F $=0.000$. Jadi Sig F $<5 \%(0.000<$ 0.05), dengan demikian Ha diterima dan Ho ditolak yang berarti bahwa secara serempak variabel $\mathrm{X} 1, \mathrm{X} 2, \mathrm{X} 3$ berpengaruh signifikan terhadap variabel Y. Jadi terbukti bahwa variabel DER, ROA dan DPR mempunyai pengaruh secara bersama-sama terhadap Nilai Perusahaan (PBV).

\section{Koefisien Determinasi $\left(\mathbf{R}^{2}\right)$}

Koefisien korelasi Pearson product moment Nilai Perusahaan (PBV) sebesar 0,567 Artinya besar korelasi atau hubungan antara variabel $D E R$ (X1), ROA (X2) dan variabel DPR (X3) ialah sebesar 0,567 atau sedang karena mendekati angka 1 .

Koefisien Determinasi, nilai adjusted $\mathrm{R}$ square sebesar 0,522 yang berarti bahwa 52,2\% variabel dependen (Nilai Perusahaan (PBV) dapat dijelaskan oleh ketiga variabel independen (DER (X1), ROA (X2) dan variabel DPR (X3)). Sedangkan sisanya $47,8 \%$ dapat dijelaskan oleh faktor lain yang tidak diteliti dalam penelitian ini.

\section{Analisis Regresi Linear Berganda}

Analisis Regresi Linier Berganda, diperoleh persamaan regresi linier berganda sebagai berikut:

$\hat{Y}=1,678+0,369(X 1)+0,051(X 2)-0,024(X 3)$ 


\section{DOI: http://dx.doi.org/10.35137/jabk.v8i3.594}

1) Nilai konstanta 1,678 , artinya jika DER (X1), ROA (X2) dan DPR (X3) bernilai nol, maka nilai Nilai Perusahaan (PBV) (Y) bernilai 1,678 .

2) Koefisien regresi variabel DER (X1) menunjukan nilai positif yaitu 0,369 . Hal ini menunjukan bahwa variabel DER (X1) berpengaruh positif terhadap peningkatan Nilai Perusahaan (PBV) (Y), artinya semakin tinggi tingkat DER (X1) akan menyebabkan semakin meningkat nilai Nilai Perusahaan (PBV) (Y).

3) Koefisien regresi variabel ROA (X2) menunjukan nilai positif yaitu 0,051 . Hal ini menunjukan bahwa variabel ROA (X2) berpengaruh positif terhadap peningkatan Nilai Perusahaan (PBV) (Y), artinya semakin tinggi tingkat ROA (X2) akan menyebabkan semakin tinggi pengaruhnya terhadap Nilai Perusahaan (PBV) (Y).

4) Koefisien regresi variabel DPR (X3) menunjukan nilai negatif yaitu 0,024 . Hal ini menunjukan bahwa DPR (X3) berpengaruh negatif terhadap peningkatan Nilai Perusahaan (PBV) (Y), artinya semakin baik tingkat DPR (X3) akan menyebabkan semakin rendah Nilai Perusahaan (PBV) (Y).

\section{Uji Signifikansi Parsial (Uji t)}

Berikut ini adalah tabel hasil pengujian secara parsial sebagai berikut:

1) Hipotesis 1: Debt Equity Ratio (DER) mempunyai pengaruh signifikan dan positif terhadap Nilai Perusahaan $(P B V)$

Berdasarkan hasil uji signifikan parsial nilai uji t hitung Debt Equity Ratio (DER) sebesar 0,409 dengan tingkat signifikan 0,004. Sehingga disimpulkan bahwa H1 diterima, artinya secara parsial bahwa variabel Debt
URNAL AKUNTANSI DAN BISNIS KRISNADWIPAYANA

Volume 8 Nomor 3 (September - Desember) 2021 Equity Ratio (DER) berpengaruh terhadap Nilai Perusahaan (PBV).

2) Hipotesis 2: Return On Asset (ROA) mempunyai pengaruh signifikan dan positif terhadap Nilai Perusahaan $(P B V)$.

Berdasarkan hasil uji signifikan parsial nilai uji t hitung Return On Asset (ROA) sebesar 0,310 dengan tingkat signifikan 0,021. Sehingga disimpulkan bahwa $\mathrm{H} 2$ diterima, artinya secara parsial bahwa variabel Return On Asset (ROA) berpengaruh positif terhadap Nilai Perusahaan (PBV).

3) Hipotesis 3: Deviden Payout Ratio (DPR) mempunyai pengaruh signifikan dan Negatif terhadap Nilai Perusahaan $(P B V)$.

Berdasarkan hasil uji signifikan parsial nilai uji t hitung Deviden Payout Ratio (DPR) sebesar 0,591 dengan tingkat signifikan 0,000. Sehingga disimpulkan bahwa H3 ditolak, artinya secara parsial bahwa variabel Deviden Payout Ratio (DPR) berpengaruh Negatif terhadap Nilai Perusahaan $(P B V)$.

\section{Pembahasan}

1. Struktur Modal (DER) mempunyai pengaruh signifikan dan positif terhadap Nilai Perusahaan (PBV).

Hasil penelitian ini menunjukkan bahwa bila Struktur modal (DER) meningkat, maka Nilai Perusahaan (PBV) meningkat.

Perusahaan yang mempunyai struktur modal (DER) yang semakin tinggi, menggambarkan kondisi yang kurang baik bagi perusahaan. Peningkatan hutang berpengaruh terhadap besar kecilnya laba bersih yang tersedia bagi para pemegang saham termasuk dividen yang diterima karena kewajiban untuk membayar hutang lebih diutamakan daripada pembagian dividen. Hasil Penelitian didukung oleh Ashari Hidayat (2013) dan Umi, Gatot dan Ria (2012) dimana 
DOI: http://dx.doi.org/10.35137/jabk.v8i3.594

hasil yang diperoleh menunjukkan Struktur modal (DER) berpengaruh positif dan signifikan terhadap nilai perusahaan (PBV).

2. Profitabilitas (ROA) mempunyai pengaruh signifikan dan positif terhadap Nilai Perusahaan (PBV).

Profitabilitas yang tinggi menunjukkan prospek perusahaan yang bagus sehingga memicu permintaan saham oleh investor (Novari dan Lestari, 2016). Semakin tinggi rasio profitabilitas makan semakin tinggi pula nilai perusahaan.

Rizqia et al. (2013) juga menyatakan bahwa keuntungan yang tinggi akan memberikan indikasi prospek perusahaan yang baik sehingga memicu investor untuk meningkatkan permintaan terhadap saham perusahaan sehingga mempengaruhi nilai perusahaan.

Hal ini menjadi dasar pengambilan keputusan investor bahwa perusahaan dengan kemampuan perolehan laba lebih tinggi lebih mampu untuk meningkatkan kemakmuran dari pemegang saham

Hasil penelitian ini didukung oleh Carningsih (2012), Dwi Ayuningtyas (2013) dan Umi, Gatot dan Ria (2012). Jadi, jika rasio Profitabilitas (ROA) meningkat maka Nilai Perusahaan (PBV) akan meningkat begitu pula sebaliknya.

3. Kebijakan Dividen (DPR) mempunyai pengaruh terhadap Nilai Perusahaan (PBV)

Hasil uji dan olah data menunjukkan bahwa terdapat pengaruh negatif dan signifikan antara Kebijakan Dividen (DPR) terhadap Nilai Perusahaan (PBV) yang berarti bahwa bila variabel Kebijakan Dividen (DPR) meningkat, maka Nilai Perusahaan (PBV) akan turun.

Dividend payout ratio adalah rasio antara dividen yang dibayarkan dibandingkan dengan jumlah laba bersih per lembar saham yang
URNAL AKUNTANSI DAN BISNIS KRISNADWIPAYANA

Volume 8 Nomor 3 (September - Desember) 2021 diperoleh perusahaan." Besarnya dividend payout ratio dijadikan ukuran oleh para investor yang hendak menanam modal pada saham di bursa efek.

Hasil didukung oleh Eva Eko Hidayati (2012), Azhari Hidayat (2013), Dwi Ayuningtyas (2013), Wardjono (2012) dan Umi, Gatot dan Ria (2012). Jadi, jika Kebijakan Dividen (DPR) meningkat maka Nilai Perusahaan (PBV) akan turun begitu pula sebaliknya.

\section{KESIMPULAN DAN SARAN}

\section{Kesimpulan}

Berdasarkan analisis dan pembahasan diatas maka dapat ditarik kesimpulan yaitu : (1). Struktur Modal (DER) mempunyai pengaruh signifikan dan positif terhadap Nilai Perusahaan (PBV) (2). Profitabilitas (ROA) mempunyai pengaruh signifikan dan positif terhadap Nilai Perusahaan (PBV) (3). Struktur Modal (DER), Profitabilitas (ROA) dan Kebijakan Dividen (DPR) secara simultan atau bersama-sama mempunyai pengaruh signifikan dan positif terhadap Nilai Perusahaan (PBV) karena dari hasil uji hipotesis nilai signifikansi $\mathrm{F}<0,05$.

\section{Saran}

Bagi Investor jika ingin memaksimalkan Nilai Perusahaan sebaiknya harus memperhatikan tingkat Struktur Modal (DER) dan menekan rasio ini supaya memiliki nilai yang kecil, harus mampu meningkatkan rasio profitabilitas karena semakin tinggi rasio profitabilitas maka akan semakin besar nilai perusahaan, harus mampu mengatur kebijakan dividennya (DPR) agar tidak terlalu berlebihan dan tidak terlalu kecil. karena semakin 
Printed ISSN : $2406-7415$

Electronic ISSN : $2655-9919$

DOI: http://dx.doi.org/10.35137/jabk.v8i3.594

tinggi rasio DPR maka akan semakin rendah nilai perusahaan

Bagi Peneliti Selanjutnya, disarankan agar mengikutsertakan variabel lain yang masih relevan dengan penelitian, seperti kepemilikan manajerial, kepemilikan institusional, dan Ukuran Perusahaan serta memperluas sektor penelitian tidak hanya di sektor Perusahaan Otomotif serta dapat menggunakan sampel yang lebih banyak. Sehingga diharapkan akan memperoleh kesimpulan yang lebih baik.

\section{DAFTAR PUSTAKA}

Alicia,Y. P. 2013. Pengaruh Ukuran Perusahaan Pertumbuhan Perusahaan, Opini Audit Tahun Sebelumnya terhadap Opini Audit Going Concern pada Perusahaan Manufaktur yang Terdaftar di Bursa Efek Indonesia, Skripsi, Jurusan Akuntansi, Padang: Universitas Negeri Padang.

Ang, Robert. 2010. Buku Pintar Pasar Modal Indonesia 7 th. Edition. Jakarta: Media Soft Indonesia

Ayuningtias, Dwi. 2013. Pengaruh Profitabilitas Terhadap Nilai Perusahaan: Kebijakan Dividen Dan Kesempatan Investasi Sebagai Variabel Antara. Jurnal Ilmu dan Riset Akuntansi Volume 1 Nomor 1

Brigham, Eugene F. dan Joel F. Houston, 2011. Dasar-dasar Manajemen Keuangan, Buku Satu, Edisi keduabelas, Alih Bahasa Ali Akbar Yulianto. Jakarta: Salemba Empat.

Carningsih. 2012. Pengaruh Good Corporate Governance Terhadap Hubungan Antara Kinerja Keuangan Dengan Nilai Perusahaan (Studi Kasus Pada
Volume 8 Nomor 3 (September - Desember) 2021 Perusahaan Property Dan Real Estate Yang Terdaftar Di Bursa Efek Indonesia). Jurnal Akuntansi Universitas Gunadarma.

Dendawijaya, Lukman. 2009. Manajemen Perbankan. Edisi Kedua. Jakarta: Ghalia Indonesia.

Dwipratama, Gede Priyana. 2009. Pengaruh PBV, DER, EPS, DPR dan ROA terhadap harga saham (study pada perusahaan food and beverage yang terdaftar di BEI. Skripsi Jurusan Akuntansi Fakultas Ekonomi Universitas Gunadarma.

Ghozali, Imam. 2012. Aplikasi Analisis Multivariate dengan Program IBM SPSS 20. Semarang: UNDIP.

Gibson, Charles H. 2009. Financial Reporting \& Analysis 11th Edition. USA: SouthWestern

Gitman, Lawrence J. 2006. Principles of Managerial Finance, seventeenth edition. Massachusetts: AddisionWesley Publishing Company.

Hanafi, Mamduh M dan Abdul Halim. 2009. Analisa Laporan Keuangan. Yogyakarta: YKPN.

Harahap, Sofyan Syafri. 2007. Teori Akuntansi, Edisi Revisi 9. Jakarta: PT. Raja Grafindo Persada

Hidayat, Azhari. 2013. Pengaruh Kebijakan Hutang Dan Kebijakan Deviden Terhadap Nilai Perusahaan (Studi Empiris Pada Perusahaan Manufaktur Yang Terdaftar Di BEI). Jurnal Akuntansi Universitas Negeri Padang. 
Printed ISSN : $2406-7415$

Electronic ISSN : $2655-9919$

DOI: http://dx.doi.org/10.35137/jabk.v8i3.594

Hidayati, Eva Eko. 2010. Analisis Pengaruh DER, DPR, ROE, Dan SIZE Terhadap PBV Perusahaan Manufaktur Yang Listing Di BEI Periode 2005-2007'. Skripsi. Semarang: Universitas Diponegoro.

Horne, James C Van dan John M. Wachowicz, JR, 2005. Prinsip-Prinsip Manajemen Keuangan. Jakarta : Salemba Empat.

Husnan dan Pudjiastuti. (2012). Dasar-Dasar Manajemen Keuangan (6 th ed).Yogyakarta: UPP STIM YKPN.

Husnan, Suad dan Eny Pudjiastuti. 2006. Dasar - Dasar Manajemen Keuangan, Edisi 5. Yogyakarta: UPP STIM YKPN.

Husnan, Suad. 2008. Manajemen Keuangan: Teori dan Penerapan Edisi 4. BPFE Yogyakarta.

Jama'an. 2008. Pengaruh Mekanisme Corporate Governance, Dan Kualitas Kantor Akuntan Publik Terhadap Integritas Informasi Laporan Keuangan (Studi Pada Perusahaan Publik Di BEJ), Tesis Strata-2, Program Studi Magister Sains Akuntansi Universitas Diponegoro, Semarang.

Jogiyanto. 2010. Teori Portofolio dan Analisis Investasi (Edisi ketujuh). Yogyakarta: BPFE

Keown, dkk. 2010. Manajemen Keuangan, edisi sepuluh jilid 2. Jakarta : Indeks.

Kusuma, Dewi Wardani dan Sri Hermuningsih. 2011. Faktor-Faktor Yang Mempengaruhi Nilai Perusahaan Pada Perusahaan Yang Terdaftar Di Bursa Efek Malaysia Dan Bursa Efek
Volume 8 Nomor 3 (September - Desember) 2021 Indonesia. Jurnal Siasat Bisnis Vol. 13 No. 2 Hal: 173-183

Lestari, Maharani Ika dan Toto Sugiharto. 2007. Kinerja Bank Devisa Dan Bank Non Devisa Dan Faktor-Faktor Yang Mempengaruhinya. Proceeding PESAT (Psikologi, Ekonomi, Sastra, Arsitek \& Sipil). 21-22 Agustus, Vol.2. Fakultas Ekonomi, Universitas Gunadarma

Mardiyanto, Handono, 2009. Intisari Manajemen Keuangan. Jakarta : Grasindo

Martono dan Agus Harjito. 2006. Manajemen Keuangan. Edisi Kedua. Yogyakarta: Ekonisia.

Munawir. 2010. Analisis Laporan Keuangan. Edisi 4. Yogyakarta: Liberty

Nuraina, Elva. 2012. Pengaruh Kepemilikan Institusional Dan Ukuran Perusahaan Terhadap Kebijakan Hutang Dan Nilai Perusahaan (Studi Pada Perusahaan Manufaktur Yang Terdaftar Di BEI). Jurnal Bisnis dan Ekonomi (JBE), Hal. $110-125$.

Ogolmagai, Natalia. 2013. Leverage Pengaruhnya Terhadap Nilai Perusahaan Pada Industri Manufaktur Yang Go Public Di Indonesia. Jurnal EMBA Vol.1 No.3, Hal. 81-89.

Ria Nofrita. 2013. Pengaruh Profitabilitas Terhadap Nilai Perusahaan dengan Kebijakan Deviden sebagai Variabel Intervening. Skripsi Akuntansi Fakultas Ekonomi Universitas Negeri Padang.

Salvatore, Dominick. 2005. Managerial Economic. Jakarta: Salemba Empat. 
Printed ISSN : $2406-7415$

Electronic ISSN : 2655 - 9919

DOI: http://dx.doi.org/10.35137/jabk.v8i3.594

Sartono, Agus. 2001. Manajemen Keuangan Teori dan Aplikasi. Yogyakarta: BPFE.

Sartono, Agus. 2010. Manajemen Keuangan Teori dan Aplikasi (4 th ed.). Yogyakarta: BPFE.

Sawir. 2009. Dasar-Dasar Analisis Keuangan. Jakarta, Mediasoft Indonesia

Siregar. 2006. Sikap Kepatuhan dalam Tindakan. Jakarta: Mitra Media.

Syamsuddin. 2009. Manajemen Keuangan Perusahaan. Jakarta: PT. Raja Grafindo Persada.

Sutrisno. 2009. Manajemen Keuangan Teori, Konsep dan Aplikasi. Yogyakarta: Ekonisia
JURNAL AKUNTANSI DAN BISNIS KRISNADWIPAYANA

Volume 8 Nomor 3 (September - Desember) 2021

Thesman, Caroline dan Juniarti. 2014.

Pengaruh Family Control Terhadap Profitabilitas dan Nilai Perusahaan Pada Sektor Pertanian. Business Accounting Review, Vol. 2, No. 1

Umi, Madiyati., Gatot Nazir Ahmad Abduh dan Ria Putri. 2012. Pengaruh

Wardjono. 2010. Analisis Faktor-Faktor Yang Mempengaruhi Price To Book Value Dan Implikasinya Pada Return Saham (Studi Kasus Pada Perusahaan Manufaktur Yang Terdaftar Di Bei). Dinamika Keuangan dan Perbankan, Vol 2 No 1, Hal: 83 - 96 .

Warren, et al. 2008. Pengantar Akuntansi. Jakarta: Salemba Empat. 